\title{
Music Teachers' Perception of Music Teaching at the Stage of Early Adolescence
}

Petra Brdnik Juhart ${ }^{\star 1}$ AND BARbara Sicherl KAFOL ${ }^{2}$

$\approx$ Based on the descriptive method of qualitative educational research, the present study explores music teaching at the stage of early adolescence in terms of general-school music teachers' viewpoints on factors defining the planning and implementation of music teaching. The study was based on qualitative analysis of data gathered in interviews with 18 teachers from nine countries (Slovenia, Argentina, Australia, USA, Turkey, Poland, Russia, Italy and Germany). The research found that music teaching based on authentic musical communication through the activities of playing, creating and listening to music was favoured by the interviewees. Among the factors affecting the presentation of music teaching at the stage of early adolescence, the quality of curricular bases and the professional competence of music teachers were emphasised. In this context, the research findings showed that music curricula in the international context do not provide a suitable curricular base for the implementation of music teaching. The problem becomes especially salient when the competences of music teachers are insufficient for the transference of the curricular platform to musical praxis through authentic ways of musical teaching. The research findings provide an insight into the complexity of the factors involved, including authentic music teaching, the music curriculum and teachers' competences, which determine the planning and implementation of music teaching at the stage of early adolescence. In addition, the findings provide a basis for further research in a broader context and for the development of guidelines for curricular updates and the modernisation of music education in general schools.

Keywords: early adolescence, music education, authentic music teaching, music curriculum, teachers' competences

$1 \quad{ }^{\star}$ Corresponding Author. Faculty of Education, University of Ljubljana, Slovenia; petra.brdnik@pef.uni-lj.si.

2 Faculty of Education, University of Ljubljana, Slovenia. 


\section{Stališča učiteljev glasbe do glasbenega poučevanja v obdobju zgodnje adolescence}

Petra Brdnik Juhart in Barbara Sicherl Kafol

$\approx$ V prispevku predstavljamo izsledke deskriptivne metode kvalitativne raziskave, v kateri smo preučevali stanje glasbenega poučevanja v obdobju zgodnje adolescence $\mathrm{z}$ vidika stališč osnovnošolskih učiteljev glasbe do dejavnikov, ki vplivajo na načrtovanje in izvajanje glasbenega poučevanja. Raziskava je temeljila na kvalitativni analizi podatkov, ki smo jih pridobili s pomočjo intervjujev z 18 učitelji glasbe iz devetih držav (Slovenije, Argentine, Avstralije, Združenih držav Amerike, Turčije, Poljske, Rusije, Italije in Nemčije). Izsledki raziskave so pokazali, da so intervjuvanci prevladujoče naklonjeni glasbenemu poučevanju, ki temelji na avtentični glasbeni komunikaciji prek dejavnosti izvajanja, ustvarjanja in poslušanja glasbe. Med dejavniki, ki vplivajo na zastopanost glasbenega poučevanja v obdobju zgodnje adolescence, so učitelji poudarili kakovost kurikularnih podlag in ustrezno strokovno usposobljenost učiteljev. V tem okviru so izsledki raziskave pokazali, da učni načrti za glasbo v slovenskem in mednarodnem kontekstu ne dajejo zadostnih kurikularnih podlag za uresničevanje glasbenega poučevanja. Problematika je izstopajoča zlasti ob pomanjkljivi strokovni usposobljenosti učiteljev za izvajanje kurikularnih izhodišč v praksi glasbenega poučevanja $\mathrm{z}$ avtentičnimi načini glasbene komunikacije. Ugotovitve raziskave nudijo vpogled v kompleksnost dejavnikov, kot so avtentično glasbeno poučevanje, učni načrt za glasbo in kompetence učiteljev, ki pogojujejo načrtovanje in izvajanje avtentičnega glasbenega poučevanja v obdobju zgodnje adolescence. Izsledki predstavljajo tudi izhodišča za nadaljnje raziskave v širšem kontekstu ter oblikovanje smernic za kurikularne posodobitve in posodobitve glasbenega poučevanja v splošnem šolstvu.

Ključne besede: zgodnja adolescenca, glasbeno izobraževanje, avtentično glasbeno poučevanje, učni načrt za glasbo, kompetence učiteljev 


\section{Introduction}

Key competences for lifelong learning involve the development of knowledge, skills and relationships that contribute to the quality of life in modern society (Council Recommendation, 2018). Lifelong competences are defined by common indicators, such as "critical thinking, problem solving, team work, communication and negotiation skills, analytical skills, creativity, and intercultural skills" (ibid., p. 1). Within this framework, documents substantiating the importance of arts and cultural education (Arts and Cultural Education, 2010; Eurydice, 2009; The Road Map for Arts Education, 2006) highlight creative expression through the arts as a means of fulfilling goals in the cultural, aesthetic and social domains of learning development. In line with international strategies of development of arts and cultural education (ibid.), the findings of a study by Bamford (2006), carried out on a sample of more than 40 countries, showed that a quality arts and cultural education influences students' holistic development by strengthening their self-confidence, self-awareness, sense of responsibility and respect for others, and improves their inclusion in the society. In this context, the present article focuses on the artistic area of music education in the period of early adolescence.

Starting at around the age of 12 years, adolescence is the process of gradual psychophysical maturing into an adult person (Zupančič, 202ob). In delimiting individual developmental periods, the present study follows Braconnier (2001, p. 32 ), who divides adolescence into three stages, starting with puberty: early adolescence (ages 10 to 14), middle adolescence (ages 15 to 19) and late adolescence (ages 20 to 24). During adolescence, connections between various parts of the brain are established and changes occur especially in the cerebral cortex responsible for conceptual and abstract thinking, new approaches to problem solving and expansion of our consciousness (Siegel, 2014; Thomas, 2016). Furthermore, changes in cognitive development cause an increase in emotionality and mood swings (Zupančič, 2020a), which, in a teenager, trigger the development of identity and developmental shifts in thinking about who they are and who they can become (McClellan, 2017; Siegel, 2014). Music has an important place in this context, often serving as a regulator of a teenager's emotional states, and is linked to the formation of self-image (Campbell et al., 2007; North et al., 2000). Research findings (Sangiorgio, 2016, 2020) also show that engaging in music in a group contributes to the development of positive interaction and the level of organisational abilities. Engaging in music enables acceptance and communication of ideas among the members of a group, which contributes to the development of social interaction. Moreover, it encourages the development of thinking strategies, such 
as memorisation, comprehension, use, analysis, synthesis and evaluation (ibid.), all of which contribute to the development of the competence of lifelong learning. In the international general education environment, music education is implemented through a variety of curricular models with various starting points for planning didactic elements. The present study is based on Bernstein's theory of the pedagogic device (2003), which defines formal education through three message systems: curriculum, pedagogy and evaluation, where "curriculum defines what counts as valid knowledge, pedagogy defines what counts as a valid transmission of knowledge, and evaluation defines what counts as a valid realization of this knowledge on the part of the taught" (Bernestin, 2003, p. 77). This theoretical basis was applied to music education in the period of adolescence (age 12 to 18) by Philpott and Wright (2018), who defined it with elements of pedagogical discourse at the level of "strong/weak/mixed" curricula. In the "strong" curricular basis model, didactic elements are defined rather in detail and guide the teacher in the implementation of the learning process, over which the teacher has stronger control. In the forefront, there is a teacher-centred approach in which "the contents are clearly defined, chosen, and controlled by the teacher, who imposes strong boundaries on what 'counts' as musical learning and teaching. The teacher also strongly frames the organization of pupils, the teaching strategies employed, and the materials chosen" (Philpott \& Wright, 2018, p. 230). In contrast, "weak" curricular bases enable a more open planning of didactic elements for creative and activity-based implementation of the learning process, as "the contents are not clearly defined, chosen, and controlled by the teacher, and no strong boundaries as to what 'counts' as musical learning and teaching are imposed. /... / pedagogy is similarly weakly framed in that the teaching strategies employed and the materials chosen are negotiated with pupils. /... / they are also encouraged to assess and evaluate their own work based on their interpretation of the stimulus" (ibid., p. 229). There are also strong links with students' music-making outside school. Thus, "weak" curricular bases include a student-centred approach in which the teacher and the student are co-creators of the learning process and co-makers of the curriculum, emphasising the "values of self-expression, pupil-centredness, discovery, creativity, imagination, and relevance" (ibid., p. 237). The two approaches can also be combined in a so-called "mixed" model, which establishes a flexible relationship between the aforementioned elements of the learning process. In this context, the present paper deals with the use of curricular bases of the "strong/weak/mixed" models (ibid.) to plan music education in the period of early adolescence.

Based on the above theoretical starting points for music education planning, we can conclude that music teaching and learning (including) in early 
adolescence is influenced by a number of factors. Among them, we would like to highlight the worrying research results that show that teaching arts-related subjects represents a great personal and professional challenge to teachers who lack self-confidence and professional competence in the area (Arts and Cultural Education, 2010; Bamford, 2006; Eurydice, 2009; Sicherl Kafol, 2015). Primary education teachers in particular lack the professional competence to implement various teaching and learning methods and adjust arts education (including music education) to the different needs and capabilities of children (Dobovičnik, 2016; Elliott \& Silverman, 2015). The findings of international and Slovenian research also show that approaches to teaching music are often incompatible with the needs of students, who consequently often express negative attitudes towards music education in general schools (McPherson \& O'Neill, 2010; North et al., 2000) and indicate a desire for more authentic musical experience (singing and instrument playing) and less emphasis on a theoretical approach with prevailing verbal explanation (Habe \& Tandler, 2013). Conversely, research (Bucura, 2019) shows that active music making in the formal school setting produces anxiety and low self-efficacy in students who "initially look for an escape route toward the familiarity of notetaking and sitting at the desk" (ibid., p. 6). Therefore, music teacher planning should be more attentive to learners' psychosocial wellbeing (ibid.). In order to understand the needs of adolescents, music teachers should develop their own personal competencies to foster "the development of learners' emotions, empathy, attitudes and values based on personal experience of musical-artistic activity" (Davidova, 2019, p. 105). Music education that enables personal experience of musical activities is also the first step towards overcoming the low status that music education seems to have in comparison with other school subjects (McPherson \& O'Neill, 2010), despite the fact that music plays an important role in the lives of adolescents (Campbell et al., 2007).

In line with the identified problem, the research objectives are oriented towards studying the state of music education of early adolescents in terms of general-school music teachers' viewpoints about factors that define the planning and implementation of music education.

In accordance with the research objectives, we posed the following research questions:

1. What are general-school music teachers' viewpoints about factors determining the planning of music education at the stage of early adolescence? 2. What are general-school music teachers' viewpoints about factors defining the implementation of music education at the stage of early adolescence? 


\section{Method}

In conducting our research, we applied the descriptive method used in qualitative educational research.

The study involved 18 music teachers from nine different countries. Most of the interviewees were female (of the 18 participants, 13 were female and 5 male). The participants' ages ranged from 26 to 60 years, with a median age of 43 years ( $I Q R=13.25$ ). All of the participants were formally qualified music teachers. Their teaching experience ranged from 2 to 40 years, with a median teaching experience of 14.5 years $(\mathrm{IQR}=14)$.

For data collecting, we used semi-structured group interviews conducted at international music conferences in Slovenia ( $1^{\text {st }}$ group) and Austria ( $2^{\text {nd }}$ and $3^{\text {rd }}$ groups) in July 2019. The participants accepted the invitation to participate randomly. The interviews, which were conducted face-to-face and lasted approximately 60 minutes, were recorded on video and audio. The first group consisted of four music teachers from Slovenia, the second was made up of six teachers from Australia, Italy, Argentina and the USA, and the third one comprised eight music teachers from Turkey, Australia, Poland, Russia, Italy and Germany. The recorded interviews were transcribed verbatim, and the transcriptions checked and approved by the interviewees. Between them, the interviewees made a total of 315 statements. In the following sections, each statement is marked with the group number (group one: I; group two: II; group three: III), followed by the number of the statement (e.g., S1), the name of the interviewee's country (e.g., Slovenia) and the consecutive number of the interviewee within his or her group (e.g., 1).

The analysis of the transcripts was performed with open coding. The parts of the text that were relevant in terms of achieving research objectives were used. The text was marked with a system of codes that were later combined into categories devised on the basis of criteria related to factors determining the planning and implementation of music education in early adolescence.

\section{Results}

In the interviews, the participating teachers expressed their viewpoints on the factors determining the planning of authentic music education in early adolescence, herein defined with the categories of weak and strong curricular bases. 


\section{Weak Curriculum}

The participating teachers' attitudes to the curriculum express their inclination towards open planning of music education that should enable creative and active realisations of the learning process. According to them, the curriculum should allow for autonomous planning of learning content, processes and other didactic elements, and focus on defining learning skills. With a "weak" curriculum, students would have the possibility of actively engaging in music education, providing initiatives and suggestions, and co-shaping the learning process.

"We have curriculum standards, but they don't have anything to do with content. They prescribe certain skills." (II / S39 / USA-1) /... / "In Germany we changed a curriculum. We have to transport more competences to the students. The lessons should be changed in more working process, not working frontal. Pupils should experience, construct situations in which students can do it by themselves." (III / S74 / Germany)

According to the interviewees, the planning of musical activities and learning strategies should be left to the autonomous decision of teachers, which indicates that they are in favour of an open, "weak" curriculum. The curriculum should allow for creative and active realisations of music education with the prevalence of musical and motor communication and the use of modern technology.

"I try not to speak but to start the class with singing, games." (II / S2O / Argentina) /.../ "There is always some singing. There is always an instrumental piece that they can do. There will always be something that involves technology." (II / S12 / Australia-1) /... " "Percussion, clapping game, traditional song of south or north Italy." (III / S25 / Italy-3) /.../ "I use a lot of games, a lot of competition as a way as like assessment. In order for me to be able to tell if they understood a rhythm concept, I am gonna have them play rhythm baseball where they have to compete to have the rhythm right". (II / S6/ USA-1) /.../ "Whether there'll be structure showed through choreography that they devise, or even pitch through movement, there's always movement." (III / S22 / Australia)

The presence of "weak" curricular bases is also reflected in the interviewees' attitudes towards planning learning content, which should take into account students' interests. In their opinion, including musical content suggested by students is not a deviation from quality music teaching, but rather a bridge to dealing with a variety of genres and styles, as defined in the curriculum. As an example, they mentioned film music, which students know from 
informal environments and which enables a connection with the musical content of various genres within the framework of a formal learning environment. "I use pop music when the boys bring it in." (III / S30 / Australia) / ... / "Children love to play melodies they know." (I / S143 / Slovenia-4) /.../ "So taking stuff that they knew and are able to then extract the concept from and applying it to some other music so they could see "Oh, cool, this music doesn't just exist in a vacuum, everything is influencing everything". (II / S59 / USA-1) "It proved efficient to mention a film this music was in - that attracted them even more." (I / S104 / Slovenia-4) /.../ "It is not true that students are not able to listen classical music. If you say: "Listen to the music!" and in 20 minutes they say "No, I am boring...please stop the music!" But if you do it with movement, with activities they will appreciate it a lot." (III / S32 / Italy-2)

The interviewees also highlighted the advantages of "weak" curricular bases in terms of learning forms that should foster group work, giving students an opportunity to cooperate on their own accord and develop mutual relationships.

"If possible, they prepare a group presentation with a projection." (I / S97 / Slovenia-3) /... " "I do lots of whole class stuff at the beginning, and if it's group work, I use random choice. I want to foster that everybody has a value to add to everything that we do." (II / S79 / Australia-2)

\section{Strong Curriculum}

The participating teachers expressed prevailingly negative attitudes towards "strong" curricular bases that direct them towards planning the didactic elements of music education, claiming that this made it difficult for them to enactive music teaching.

"For me, curriculum is the problem. Because Ministerium decided we have to follow this structure." (III / S63 / Poland) / ... " "For me, this is a great dilemma. What the curriculum imposes on me drags me into a kind of narrowness." (I / S72 / Slovenia-2)

Within this framework, the teachers were also critical of the standards of knowledge, which, according to them, should define the achievements of authentic musical activities to a greater extent, particularly achievements in the area of musical literacy.

"We mostly focus on playing and reading notes." (II / S14 / USA-2) / ... /

"This year I've put more emphasis on the use of notation and reading from it. I think this could be given more weight." (I / S89 / Slovenia-2) 
/... "A written record of a musical language - I find this very operative, something a primary school child could carry on into his or her life." (I / S91 / Slovenia-3)

The interviewees from Slovenia also pointed out the problem of the national examination, which, in their opinion, does not include authentic methods of examination and assessment of musical achievements.

"In the year of preparation [for the national examination - authors' note] we spent less time singing and playing instruments." (I / S81 / Slovenia-1) /.../ "At the last one [i.e., national examination - authors' note] it was necessary to add some rhythmic patterns to a folk song. This would make sense if students could actually imagine what they write and if they had instruments to play it, but it's just a transcription, then this is not creating at all." (I / S110 / Slovenia-3)

The participating teachers were prevailingly in favour of regular examination of musical abilities and knowledge, pointing out that the teacher should focus on steering the learning process with timely and quality feedback on attainment of the learning goals.

"At this point the teacher intervenes and says you are doing this well; this needs a bit more attention, let's try this and that. But theoretically every child should be able to meet the standard." (II / S66 / Australia-2)

The above categories of curricular bases for planning music education at the stage of early adolescence connect with the advantages of implementing authentic music education as well as the conditions for doing so.

\section{Advantages of Authentic Music Teaching at the Stage of Early}

\section{Adolescence}

In the context of authentic music teaching, the interviewees identified the advantages of a stimulating learning environment that offers students quality stimuli for their musical and personal development. In a stimulating learning environment, with the prevalence of musical communication, students have an opportunity for creative and active musical expression, which enables the development of their musical abilities, skills and knowledge.

"Music teaching requires a change of a child or a student from the beginning of a process to the end of the process. It's changing their understanding; it's changing their level of expression as well as changing their level of knowledge." (II / S16 / Australia-2) /.../ "It's a fact that they learn 
more if they move while singing or creating on instruments than if they copy a text from a slide”. (I / S88 / Slovenia-3)

According to the interviewees, a stimulating learning environment is particularly important in early adolescence, which is a period of intense psychophysical maturing. In this period, students tend to express feelings of shame and unease during musical and motor activities.

"Psychical development is not the same - especially girls start to develop physically. It is the reason to be in shame, not to be opened for movement or anything." (III / S16 / Russia) / ... " "It is a body that is going to transform. And they feel very strong energy inside. And maybe they are not very conscious." (III / S14 / Italy) / ... "I have a feeling that students are quite closed regarding feelings". (I / S57 / Slovenia-4) / ... " "They struggle with emotions in the very short time and they can't handle it." (III / $\mathrm{S}_{15}$ / Poland) /.../ "They might not want to show that they are good at something in a big group, but they still get a lot of satisfaction from doing something well. (II / S3 / Australia-1) /... / "They do not feel safe to express something. (I / S59 / Slovenia-4) /.../ "This is the period of puberty when they are embarrassed to talk about emotions." (I / S58 / Slovenia-3)

With the increased emotional sensitivity of students, a stimulating learning environment is important, as it provides support for an exchange of opinions, views and ideas, as well as ensuring plenty of opportunities to establish mutual relationships in which they feel safe and accepted.

"They like to feel safe in their hood". (II / S3 / Australia-1) / ... " At that age group they start to change their opinion of you as an authority figure. And connecting with them on a valuable level can help with that." (II / S10 / Australia-2) /... / "I think that they want to know that you are on their team that you are paying attention to who they are because they also have very strong ideas of what they are interested in or what they like doing." (II / S11 / USA-1)

The interviewees also recognised the advantages of authentic music education in early adolescence with regard to students' interest in this type of music teaching. Students' gladly participate in musical activities and particularly like vocal and instrumental performing, creating and listening to music, and learning through play using various learning aids.

"Everybody likes to play, regardless of the instruments we give them, whether it is claves or a triangle." (I / S140 / Slovenia-3) /... " They adore 
clapping games. (III / S23 / Russia)" / ... "And they like material like sticks and balls." (III / S23 / Russia) / . .. / "The games, the movement, different kind of movement." (III / S35 / Poland)

The participating teachers also expressed interest in authentic music teaching that is implemented through various realisations of the Orff and Kodaly concepts, both of which emphasise musical communication as the prevailing approach. They were critical of non-authentic approaches to music education in which verbal communication and verbal teaching methods prevail. According to the teachers, these traditional music education models are still very common in practice, resulting in authentic music teaching often being regarded as a novelty and an experiment.

"Normally children don't create music." (III / S75 / Germany) / ... / "Believe me if you come to Italy to some schools, they don't do anything." (III / S 39 / Italy-3) / ... " "There is huge variety of how music is taught. You have Orff people, and you have Kodaly people and people who are mostly Orff but also do a little Kodaly. You have people who do entirely their own thing. You have schools that have general music and other schools with no music." (II / S38 / USA-1) /.../ "If they saw my class, they would see certainly not a traditional thing. They would see that as an experimental thing, quite different to perhaps what traditionally has been done." (III / S45/ Australia)

It is difficult to provide a clear-cut definition of traditional and authentic approaches. Nevertheless, the interviewees saw advantages in the sensible combination of the two approaches in which verbal methods should complement previously acquired authentic learning experience.

"For me this [i.e., verbal methods - authors' note ] is not a negative part. If before you explore, create, it is a logical consequence. Because they are satisfied with what you did with the body, phrasing, the movement, and so on. And then you arrive at the theory. Fantastic! Why not?" (III / S47 / Italy-2)

\section{Conditions for Implementing Authentic Music Teaching at the Stage of} Early Adolescence

Among the conditions necessary for implementing authentic music teaching and learning, the interviewees emphasised the importance of appropriate spatial conditions that enable unhindered musical and motor expression. The classroom should be big enough, with appropriate acoustics, and without unnecessary additional equipment, such as desks. 
"I have a classroom with excessive echo." (I / S127 / Slovenia-4) /... " "I have no material. I have no space in my school." (III / S63 / Turkey-2) /.../ "I think it is more and more privilege to have space to do something. For everything. To have a room for movement. I think it is a paradise." (III /S65 / Germany)

The participating teachers also underlined the importance of appropriate time-related working conditions and the number of students in the class. They pointed out that the number of hours allocated to music education is insufficient for the realisation of creative and activity-based teaching and learning approaches. Within this framework, they also presented several options for the authentic examination and assessment of musical achievements in numerous classes.

"An hour a week is not nearly enough time to create an atmosphere in which we could communicate our feelings to each other, so that they could then share this with their parents and transmit the experience." (I / S54 / Slovenia-1) "We create a composition and play it. Then the students play in quartets or octets. This way I manage to assess the entire class in one lesson, and the students also listen to each other and assess each other." (I / S154 / Slovenia-2)

The advantages of and conditions for implementing authentic music education connect with the categories of the personal and professional competences of music teachers.

\section{Personal Competences of Music Teachers}

In their views of music teaching of early adolescents, the interviewees expressed their personal interest and motivation regarding implementing authentic music education. The descriptions of their experience of the learning process were often accompanied with humour.

"I can feel more comfortable." (III / S24 / Turkey-1). "I use the voice. For me is so funny." (III / S25 / Italy-3) / ... "Whenever I talk to other people [about teaching teenagers - authors' note] they always go 'Oh, ok...' and I say 'No, no, actually it's a lot of fun!'” (II / S5 / USA-2)

Their statements also reveal an empathy towards students and a feeling for their needs.

"They really want to have fun, to be free." (III / S35 / Poland) / ... " "Music time for children is sometimes paradise." (III / S74 / Germany) /.../ “They adore clapping games. (III / S23 / Russia)" /... " "A good way that 
I do that is that I make a couple of mistakes early on so that they can see that I am fallible." (II / S1o / Australia-2)

\section{Professional Competences of Music Teachers}

Among the professional competences that influence the implementation of music education in adolescence, the interviewees pointed out teaching and musical skills, particularly in the field of music arrangements and the organisation of musical events at school.

"I say bring me your favourite song and I'll arrange it." (III / S29 / Italy) / ... /

"I take music from movies and arrange it for my children." (III / S35 / Poland)

Besides positive examples of professional competences, they also mentioned the problem of inadequate professional competence, especially with regard to primary education teachers.

"Curriculum is being designed to be delivered by teachers who know nothing about music. So it is being simplified and simplified until there is basically nothing, which is great for me because I can pretty much do what I like, but in terms of an overall picture of music education in Australia is shocking. You can actually tick the box saying that you've taught music without the kids ever playing any music, without being involved physically in any music at all. And I think that's ridiculous." (III / S67 / Australia) /... " "It depends on the teacher's affinity. [referring to activitybased music teaching at primary education level - authors' note]" (I/ S121 / Slovenia-3) / .../ "If we [music teachers - authors' note] could teach music earlier [at the lower level - authors' note], then there would be continuity and we wouldn't have any problems." (I / S108 / Slovenia-2)

Furthermore, the participating teachers highlighted the inappropriate status of the subject, especially in cases where music education at school is implemented deficiently or not at all.

"You have schools that have general music and other schools with no music." (II / S38 / USA-2) /.../ "And it's very unfortunate that in some school systems there are no music teachers, so there is no music education for some students. So, the reality is they do nothing, they have no music education." (III / S45 / Australia)

They were also critical about their own professional competence for implementing differentiation and individualisation of lessons (e.g., teaching students with special needs or foreign students), examination, assessment and 
working with parents.

"When I studied, we didn't even talk about special needs yet. Individualisation of lessons - you do something with a group and something else with individuals." (I / S41 / Slovenia-3) / ... " "The psychology we did have was more or less general. I learn the most from our school counsellor." (I / S42 / Slovenia-4) /... "I started learning when I started working that's my experience." (I / S46 / Slovenia-1)

The categories of personal and professional competences indicate a connection with the previously mentioned categories of curricular bases and the advantages of and conditions for authentic music education implementation.

\section{Factors of Music Teaching to Students in Early Adolescence}

Summarising the findings of the study, we can emphasise that the factors of teaching music to students in early adolescence, including the music curriculum, teachers' competences and authentic music teaching, are intertwined in a complex way and are mutually dependent, as shown in the diagram below (Figure 1). Thus, the implementation of "weak", "mixed" and "strong" curricular bases, which determine the nature of the pedagogical interaction and didactic elements of music education (Philpott \& Wright, 2018), depends on the music teacher's personal and professional competences, which influence the teaching through authentic approaches to music education and vice versa.

\section{Figure 1}

Factors of Music Teaching at the Stage of Early Adolescence

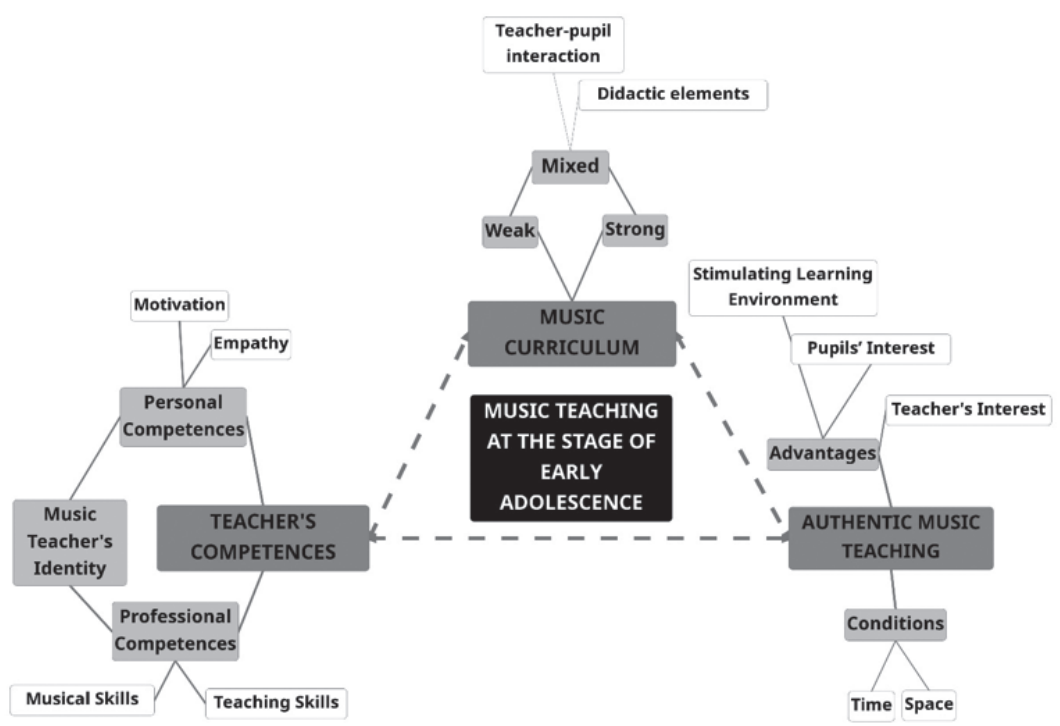




\section{Discussion}

The research results demonstrate the complexity of the factors determining the planning and implementation of music education at the stage of early adolescence.

In line with research question 1, which concerns general-school music teachers' viewpoints on planning music education at the stage of early adolescence, the music curriculum factor can be determined on the basis of categories of curricular models.

\section{Music Curriculum}

In their viewpoints on the curricular bases of music education at the stage of early adolescence, the participating music teachers identified advantages and disadvantages of the prevailing "weak", "strong" and "mixed" models.

The research findings show prevailingly positive attitudes to open curricular bases that, in accordance with the "weak" model, enable the teacher to autonomously and creatively plan the didactic elements of music education. In line with Young (2013, p. 106), the participating teachers evaluated the relevance of curricular models from the following points of view: "Is this curriculum meaningful to my students? [...] What are the meanings that this curriculum gives my students access to? [...] Does this curriculum take my students beyond their experience and enable to envisage alternatives that have some basis in the real world?"

Weak curricular bases of authentic music education enable the implementation of musical activities and content that adolescent students deem personally important and are aligned with their interests, needs and motivation. However, besides the indicated advantages of "weak" curricular bases, the research findings also reveal the disadvantages of such a model in terms of the professional competences of music teachers, who are often not up to the task of the quality implementation of music education, and are therefore more comfortable with "strong" models that provide more precise guidelines for planning the didactic elements of music education.

The participating teachers were critical of the closed "strong" model, which "reduces the power of the pupil over what, when and how he receives knowledge, and increases the teacher's power in the pedagogical relationship" (Bernstein, 2003, p. 81), also in terms of the examination and assessment of knowledge. As they pointed out, the curricular bases of "strong" models do not include authentic achievements of performing, listening to and creating music, neither in the segment of planning the modes of examination and assessment of knowledge, nor in the segment of standards of knowledge. 
The identified advantages and disadvantages of "weak" and "strong" models suggest the relevance of "mixed" curricular bases that can contribute to the quality of music education (including) in early adolescence. When considering the balance of open and closed models, it is necessary to take into account the fact that "students' everyday knowledge should not form the basis for the curriculum, but it may be useful as a pedagogic tool for bridging the gap between informal and formal knowledge" (Pountney \& McPhail, 2019, p. 489). Based on the advantages and disadvantages of "weak" and "strong" models, we can conclude that music education should provide authentic learning experience to make relevant connections between informal and formal knowledge through the implementation of didactic elements of a "mixed" curricular model.

In line with research question 2, which examined the music teachers' viewpoints on the factors determining the implementation of music education in early adolescence, the authentic music teaching factor can be determined on the basis of the categories of the conditions for and advantages of teaching through musical communication.

\section{Authentic Music Teaching}

The participating music teachers' viewpoints on teaching early adolescents highlighted the advantages of authentic music teaching and the conditions for its implementation.

Among the advantages of authentic music teaching in early adolescence, which includes performing, listening and creating musical activities, as well as "composition and music appreciation (in the critical sense)" (Eurydice, 2009, p. 12), the research findings highlighted the importance of a stimulating learning environment that offers students support in expressing their feelings, views and ideas, and provides a sense of safety and acceptance. In line with other research findings that identified the advantages of enactive music teaching (Habe $\&$ Tandler, 2013), we conclude that authentic music teaching can be realised in a stimulating learning environment in which the teacher responds to the initiatives of the students, takes into account their suggestions, and enables them varied and creative ways of musical communication. In accordance with Bernstein's pedagogic discourse of pedagogic relationship and the concept of frame, which, as explained by the author, "refers to the degree of control teacher and pupil possess over the selection, organization, pacing and timing of the knowledge transmitted and received in the pedagogical relationship" (Bernstein, 2003, p. 80 ), we can speak of a prevailingly open "weak" model. Within such a model, "the pupils have some control over their organization and the teaching strategies, and open interaction is encouraged in the creative process" (Philpott \& 
Wright, 2018, p. 229). In this model, the teacher takes into account the students' initiatives in the implementation of music education and acts as a facilitator and enabler of the learning process.

In the pedagogical relationship of the "weak" model, students' and teachers' interest in authentic music education is also established. In line with the findings of other studies (Habe \& Tandler, 2013; North et al., 2000), we conclude that students in the period of adolescence want authentic musical experience in which they can use musical communication to express their identity and connect the learning experience of formal education with musical experience acquired outside school. In this way, a bridge between the formal and informal learning environments is also formed. We have noted that students in early adolescence are disinclined to the traditional, i.e., non-authentic, approach to music teaching, which prevailingly includes verbal communication and often leads to a decline in their interest and a negative attitude towards music education (North et al., 2000). The importance of authentic music education is therefore not just in the promotion of musical development, but also in its contribution to the formation of personal and musical self-image (ibid.) and thinking strategies (Sangiorgio, 2016, 2020), and to balancing emotional and social processes (ibid).

Among the conditions necessary for implementing authentic music education, space, time and the number of students were pointed out, parameters that should also be more appropriately defined in the curricular bases. The research findings show that spatial conditions, together with arranging the necessary equipment and aids, are often left to the initiative of the music teacher. Furthermore, if we take into account the opinion of Philpott and Wright (2018), who emphasise that authentic music teaching can only take place in a properly equipped music classroom, it is clear that more attention needs to be devoted to these issues in the curriculum. The participating teachers also noted the problem of time-related working conditions, underlining the fact that the hours allotted to music education are insufficient. As suggested by numerous studies (Bamford, 2006; Eurydice, 2009; McPherson \& O’Neill, 2010), we can therefore conclude that artistic subjects have a weaker position in comparison with other subjects (e.g., mathematics and science) that are considered important for economic or academic success. Thus, the problems of space- and time-related working conditions require more appropriate solutions in the curricular bases.

In line with research question 2 , which examined music teachers' viewpoints on the factors determining the implementation of music education in early adolescence, the music teachers' competences factor can be determined on the basis of categories of personal and professional competences. 


\section{Music Teachers' Competences}

In their views on the music education of students in early adolescence, the participating teachers also talked about personal and professional competences.

With regard to the participating teachers' personal competences, the findings highlighted their motivation to teach music to students in early adolescence through authentic musical activities, in which the students' expressed personal interest and satisfaction. In authentic music education, teachers establish an empathetic relationship towards the students, encouraging interaction with and between them, and thus facilitating an exchange of different views and ideas, all of which meet the students' personal needs and interests, and enhance their motivation. In the process of authentic music teaching, teachers experience confidence in their own self-efficacy and autonomy, which enables them to adapt to various working conditions (including unfavourable conditions). They experience the music teaching process as having an intrinsic value that helps to shape their personal identity as well as their identity as music teachers. For teachers, the directions of "strong" curricular bases, especially standards of knowledge and time- and space-related working conditions, represent obstacles to the autonomous realisation of authentic music education. Despite the well-known deficiencies of "strong" curricular bases, the participants believe that such guidelines can still be of help, especially to teachers with lower levels of professional competence.

In their views on their own professional competences, the teachers expressed the areas of teaching skills and music skills, including the ability to arrange compositions and prepare school musical events. They also critically highlighted inadequate professional competence in the field of planning the differentiation and individualisation of lessons and in teaching students with special needs. Moreover, they addressed the problem of the insufficient professional competence of primary education teachers. In line with other research findings (e.g. Habe, 2017; Jank \& Meyer, 2006; Sangiorgio, 2016, 2020; Sicherl Kafol, 2015; Zalar, 2014), this indicates that the implementation of authentic music education requires a professionally competent teacher.

\section{Conclusion}

The research findings revealed the complexity of the factors that determine the planning and implementation of music teaching at the stage of early adolescence. In terms of music education planning, the advantages and disadvantages of "weak" and "strong" curricular bases were identified. Among the 
identified advantages, we would like to point out that "weak" models enable open communication between all of the participants in the learning process and allow teachers to autonomously and creatively plan the didactic elements of music education, while "strong" models provide the necessary professional basis, especially for teachers with a lower level of self-esteem and professional competence. The advantages of both models indicate the need for a flexible combination of both approaches in a so-called "mixed" model. The research results also highlighted the fact that, in an international context, music curricula do not provide a suitable curricular basis for the planning and implementation of music teaching at the stage of early adolescence, thus posing the challenge of seeking alternative curricular solutions.

Furthermore, the implementation factors of music education in early adolescence revealed the advantages of authentic music education that enables active engagement in music through the prevalence of musical communication and connects the learning experience of formal education with musical experiences acquired outside school. In an active music teaching and learning process, the participating teachers and students fulfil their personal needs, interest and motivation, which suggests a connection with the factor of the teacher's personal and professional competences that form the music teacher's identity.

The dynamic of the relationships between the three factors - music curriculum, authentic music teaching, and the teacher's personal and professional competences - influences the complexity of music education planning and implementation (also) in early adolescence and prevents clear-cut definitions. Thus, the activities of authentic music education that can be implemented in a more or less open curricular approach, following either a "weak", "mixed" or "strong" model, depend on the level of the teacher's personal and professional competences, which in turn influence the quality of music teaching and the implementation of the curricular bases. This highlights the need for the flexible harmonisation of the music teacher's personal and professional competences with curriculum planning in order to implement authentic music education (also) at the stage of early adolescence. Further research should therefore investigate the following questions: Which segments of "strong", "mixed" and "weak" curricular models can represent the basis for further planning of authentic music education (also) in adolescence? How can we establish connections between teenage students' formal and informal musical environments? How can we improve the possibilities of the formal and continuous training of music teachers? The research findings provide a starting point for further research in a broader context, and for developing guidelines for curricular updates and the modernisation of music education in primary schools. 


\section{References}

Arts and cultural education [Kulturno-umetnostna vzgoja]. (2011). Priročnik s primeri dobre prakse iz vrtcev, osnovnih in srednjih šol - dopolnjena spletna različica [Manual with examples of good practice from kindergartens and primary and secondary schools - Revised online version]. Ministry of Education and Sport and National Education Institute Slovenia. https://www.zrss.si/ kulturnoumetnostnavzgoja/publikacija.pdf

Bamford, A. (2006). The wow factor: Global research compendium on the impact of the arts in education. Waxmann Verlag GmbH.

Bernstein, B. (2003). Towards a theory of educational transmissions (Vol. 3). Routledge.

Braconnier, A. (2001). Kako razumeti mladostnika [A guide to an adolescent]. Učila.

Bucura, E. (2019). Fostering self-efficacy among adolescents in secondary general music. General Music Today, 32(3), 5-12. https://doi.org/10.1177/1048371319834080

Campbell, P. S., Connell, C., \& Beegle, A. (2007). Adolescents' expressed meanings of music in and out of school. Journal of Research in Music Education, 55(3), 220-236.

Council Recommendation. (2018). Council recommendation of 22 May 2018 on key competences for lifelong learning. The Council of the European Union. Official Journal of the European Union. https:// eur-lex.europa.eu/legal-content/EN/TXT/PDF/?uri=CELEX:32018Ho604(o1)\&from=LT

Davidova, J. (2019). Music teacher's competences in the 21st century. Pedagogika, 134(2), 99-108. https://doi.org/10.15823/p.2019.134.6

Dobovičnik, I. (2016). Ozaveščenost razrednih učiteljev in staršev o pomenu glasbene vzgoje v prvem in drugem triletju osnovne šole [The awareness of class teachers and parents about the meaning of music education during the first and second educational cycles in primary school] (Doctoral dissertation).

Faculty of Education, University of Ljubljana.

Elliott, D. J., \& Silverman, M. (2015). Music matters: A philosophy of music education. (2nd ed.).

Oxford University Press.

Eurydice. (2009). Arts and cultural education at school in Europe. EACEA.

Habe, K. (2017). Osebnostne vrline in občutek poslanstva glasbenih pedagogov - temelj uspešne poklicne kariere glasbenega pedagoga [Personal virtues and sense of vocation - The foundation for a successful career as a music teacher]. The Journal of Music Education of the Academy of Music in Ljubljana 27, 77-93.

Habe, K., \& Tandler, K. (2013). Motivacija osnovnošolcev za glasbeni pouk [Primary school pupils' motivation for music education]. Glasba $v$ šoli in $v r t c u, 17(1 / 2), 13-35$.

Jank, W., \& Meyer, H. (2006). Didaktični modeli [Didactic models]. Zavod Republike Slovenije za šolstvo.

McClellan, E. (2017). A social-cognitive theoretical framework for examining music teacher identity. Action, Criticism, and Theory for Music Education, 16(2), 65-101.

McPherson, G. E., \& O’Neill, S. A. (2010). Students' motivation to study music as compared to other school subjects: A comparison of eight countries. Research Studies in Music Education, 32(2), 101-137. 
North, A. C., Hargreaves, D. J., \& O’Neill, S. A. (2000). The importance of music to adolescents.

British Journal of Educational Psychology, 7o(2), 255-272.

Philpott, C., \& Wright., R. (2018). Teaching, learning, and curriculum content. In G. E. McPherson

\& Graham F. Welch (Eds.), Music learning and teaching in infancy, childhood, and adolescence (Vol. 2,

pp. 222-240). Oxford University Press.

Pountney, R., \& McPhail, G. (2019). Crossing boundaries: Exploring the theory, practice and possibility of a 'Future 3' curriculum. British Educational Research Journal, 45(3), 483-501.

Sangiorgio, A. (2016). Collaborative creativity in music education: Children's interactions in group creative music making (Doctoral dissertation). University Exeter.

Sangiorgio, A. (2020). A manifesto for creative interaction in music education. In A. Sangiorgio \& W. Mastnak (Eds.), Creative interactions - Dynamic processes in group music activities (pp. 19-34). University of Music and Performing Arts Munich.

Sicherl Kafol, B. (2015). Izbrana poglavja iz glasbene didaktike [Selected chapters on music didactics]. Faculty of Education University of Ljubljana.

Siegel, D. J. (2014). Vihar v glavi: moč najstniških možganov [Brainstorm: The power of teenagers' brains]. Družinski in terapevtski center Pogled.

The Road Map of Art Education. (2006). The World Conference on Arts Education: Building Creative Capacities for the 21st Century Lisbon, 6-9 March 2006. Seoul Agenda: Goals for the Development of Arts Education. https://www.danmarksbilledkunstlaerere.dk/wp-content/ uploads/2014/o9/unesco_road_map_for_arts-education.pdf

Thomas, S. K. (2016). Music preferences and the adolescent brain: A review of literature. National Association for Music Education, 35(1), 47-53.

Young, M. F. D. (2013). Overcoming the crisis in curriculum theory: A knowledge-based approach. Journal of Curriculum Studies, 45(2), 101-118.

Zalar, K. (2014). Narativne in dialoške razsežnosti »Orff-Schulwerka« [Narrative and dialogical dimensions of "Orff-Schulwerk"] (Doctoral dissertation). Faculty of Education, University of Ljubljana.

Zupančič, M. (2020a). Čustveni in osebnostni razvoj v mladostništvu ter na prehodu v odraslost [Emotional and personal development in adolescence and in the transition to adulthood]. In M.

Umek \& M. Zupančič (Eds.), Razvojna psihologija (2nd ed., pp. 698-743). Faculty of Arts, University of Ljubljana.

Zupančič, M. (202ob). Opredelitev razvojnega obdobja in razvojne naloge v mladostništvu ter na prehodu v odraslost [Definition of the developmental period and developmental tasks in adolescence and in the transition to adulthood]. In M. Umek \& M. Zupančič (Eds.), Razvojna psihologija (2nd ed., pp. 644-665). Faculty of Arts, University of Ljubljana. 


\section{Biographical note}

Petra Brdnik Juhart is a teaching assistant in Music Didactics at the Faculty of Education, University of Ljubljana, Slovenia. Her research interests include the holistic approach to music education at all stages, especially the development of experience and understanding of music in the early years of education. She participates in congresses and seminars in Slovenia and abroad and publishes professional and artistic articles.

Barbara Sicherl-Kafol, PhD, is Professor of Music Didactic at the Faculty of Education, University of Ljubljana. Her main research areas concern the field of music education within holistic educational planning, the assessment of musical achievements, strategies and skills of lifelong learning and modern learning methods especially for primary schools. She is the author and co-author of numerous scientific and professional articles and monographs. 